\title{
Te Whakaako i Te Reo \\ Teaching Māori Using The Te Whanake Collection
}

\section{Introduction}

The widespread teaching of Māori language to adults in tertiary institutions in Aotearoa/New Zealand is a relatively recent phenomenon. However, it was taught in universities by 1929 when it was being offered as a unit for the Bachelor of Arts degree by the University of New Zealand, although there is conflicting information regarding the precise date when this started. ${ }^{1}$ It was not until 1951 that the language was actually taught by a permanent member of the faculty at any constituent college of the University of New Zealand when Professor Bruce Biggs was appointed Lecturer in Māori Studies at the University of Auckland.2 (Benton 1981: 26). The other universities and polytechnics in Aotearoa/New Zealand have gradually followed. The University of Waikato introduced Māori as a subject for a Bachelor degree early in its life in 1970 under the leadership of Tìmoti Kāretu, ${ }^{3}$ while the University of Otago, which is the oldest university in Aotearoa/New Zealand, having been established in 1869, introduced Māori as a subject only in 1981.4

It was only with the production of the Te Whanake textbooks and resources that a comprehensive series designed to teach Māori as a second language to adults has become available. Prior to the production of these resources, the material available for teaching Māori language to adults was limited to a few grammar textbooks, the best of which was Bruce Biggs' Let's Learn Mãori. Other textbooks available were designed for teaching the language to children, the most notable of which are the three textbooks of the Te Rangatahi series by Hoani Waititi for secondary schools, and the more advanced textbook by Tìmoti Kāretu called Te Reo Rangatira. There were no Māori language textbooks specifically designed for developing the receptive and productive skills of adult John Moorfield is a Professor in Māori Innovation and Development at Te Ara Poutama, the Faculty of Māori Development at AUT University. He taught for twenty-one years in the Department of Māori at The University of Waikato, and then at the University of Otago, where he became a Professor in Te Tumu, the School of Mãori, Pacific and Indigenous Studies 
learners of Māori. Some European languages such as English, French, Spanish and German have a variety of helpful and well-designed textbooks and accompanying resources for adult foreign language learners. Māori had no such resources.

With the increasingly widespread use of the Te Whanake series of textbooks and resources for Māori language learning and teaching in tertiary institutions throughout Aotearoa/New Zealand, it is probably of value for the author to make explicit some of the principles that underlie what is contained in the textbooks, the audio- and videotapes, the study guides and the teachers' manuals. As well as concentrating information about the nature of the Te Whanake series into one article, this commentary will also be of benefit to those who do not understand Māori, but wish to understand the teaching methodology that the author intended to be used with the series.

The Te Whanake series provides the basis for a structured Māori language programme from beginner level through to the advanced learner of Māori. While further resources will continue to be added to the series, with the publication in 1996 of Te Whanake 4 Te Kōhure and its set of six videotapes there was finally a comprehensive set of resources for teaching Māori to adults.

This commentary will:

- discuss the content of the textbooks and resources;

- make explicit the teaching methodology underpinning the series and how these methods are implemented;

- explain the principles used in creating the textbooks and recorded exercises; and

- discuss the pedagogic grammar of the Māori language contained in the textbooks.

While the four student textbooks are central to the series, the total set of resources needs to be considered.

\section{A general description of the textbooks and resources}

While the first textbook for beginners, Te Whanake $1 \mathrm{Te}$ Kākano, and the accompanying tape script, were initially created for the author's own teaching needs at The University of Waikato, the textbook was later revised and published in 1988 by Longman Paul (now Pearson Education New Zealand). This first textbook in the series has been reprinted (usually 
twice) each year since then. Most tertiary educational institutions and some secondary schools use the series.

Te Whanake 2 Te Pihinga followed in 1989 and Te Whanake 3 Te Māhuri was published in 1992. The fourth and final textbook in the series, Te Whanake 4 Te Köhure, together with the six videos for the listening exercises, is for upper intermediate to advanced learners and was published in 1996. Study guides for courses based on Te Whanake 1 Te Käkano, Te Whanake 2 Te Pihinga and Te Whanake 3 Te Māhuri have also been written.

The Te Whanake series evolved out of the need for Māori language resources for adults that reflected modern methods of teaching second languages. Over the last thirty years considerable advances have been made in improving second language teaching methods based on an improved understanding of how languages that are additional to a person's first language are learnt.

The teaching methodology reflected in the Te Whanake textbooks and resources is based on the way learners in a natural bilingual situation learn an additional language. These textbooks and related resources are a culmination of what is now nearly 40 years of study by the author of developments in second and foreign language teaching methodology and bilingual education, together with the practical application of teaching Māori to secondary school pupils and adults for a similar period of time.

Considerable research has been carried out in writing these materials. Searching for appropriate recorded oral and written materials suitable for the developing language of the students has also been a time-consuming task. Likewise, finding or creating illustrations to include as resources to assist learners and teachers has been important. The illustrations and cartoons have been chosen or created with teaching points in mind, as well as to add interest to the written text. Some illustrations have been created as prompts for speaking and writing practice exercises.

Further research and checking with native speakers went into the grammar and usage sections of each chapter. Some aspects of grammar and usage are not to be found in other textbooks or grammars.

The authentic oral texts selected for the videotaped listening exercises are from Māori language programmes held at the New Zealand Television Archive. Not only was careful selection required, but also negotiation with the New Zealand 
Television Archive for the use of the materials at a reasonable cost was a long process.

The following outline describes briefly what is currently contained in the Te Whanake series.

\section{Pukapuka matua - Student textbooks}

Each chapter of the student textbooks contains the following:

- Dialogues or texts of interest to adult learners to be learnt or studied by the students. Each of these contains a limited and manageable amount of new language. Authentic texts become increasingly important as learners work through the series.

- New grammar and usage contained in the dialogues and texts of each chapter are explained in the chapter in sections called 'He whakamārama'. Further examples of particular grammar or usage points are given in these sections together with some new vocabulary appropriate at the particular stage of the learners' Māori language development. Some cultural information is also contained in these sections.

- To enable learners to create their own language using particular structures, extra vocabulary is provided in some chapters under the heading 'He kupu atu anō'.

- Every chapter has a section providing listening and speaking activities. These are done by listening to recordings on audio- or videotapes or online, while the textbook provides instructions, illustrations and written material where it is needed for the exercises to be completed. Some of these exercises are designed to give practice using grammatical structures that occur in the dialogues, texts and $\mathrm{He}$ whakamārama sections. However, there is a gradual shift from a preponderance of these types of meaningful drills in $T e$ Käkano to exercises designed to develop the learners' listening skills in Te Māhuri, where video as well as audiotapes are used, and Te Kōhure where six videotapes of carefully selected authentic televised extracts from the New Zealand Television Archive have been produced for listening comprehension exercises.

- In Te Kākano special exercises, called 'Hei whakahuahua', which focus on pronunciation, are included in each chapter. Each of these concentrates on a particular 
phoneme, using Māori place names or people's names for practice. This has been included to focus on the correct pronunciation, stress and intonation, as the majority of nonMāori speakers commonly mispronounce most of these names.

- Writing exercises (Hei mahi tuhituhi), reading exercises (Hei mahi pānui) and speaking exercises (Hei mahi kōrero), or combinations of these, are provided in each chapter. The more advanced textbooks have research follow-up activities, sometimes called 'Hei mahi rangahau'. Further activities are provided in the teachers' manuals.

At the end of each textbook there is a complete list of all the new vocabulary and new meanings of particular words that occur in the textbook and on the listening and videotapes. Where relevant, page numbers are also given for references to grammar and usage sections. The English gloss also indicates the grammatical class the word belongs to as follows:

With words that belong to the class called 'universals' by Bruce Biggs, 5 the English meaning begins with 'to ...' Most also have the appropriate passive ending(s) indicated in parentheses after the Māori word, eg

hari (-a) to take, carry

Where there is a change in the form of the word when the passive ending is added, the word with its passive ending is given in full, eg

rongo (rangona) to hear, feel, smell

The class called 'statives' by Biggs' 6 or 'neuter verbs' by Ray Harlow $^{7}$ are indicated by the word 'be . . .' beginning the English meaning, eg

riro

be taken, obtained, gone

Words used only as nouns (Biggs 1973: 51-52) have only a noun in English to begin the gloss, eg

rîwai

potato

Words of the 'locative' class (Biggs 1973:53) other than place names, are indicated by the word 'the ...' beginning the English gloss, eg

tātahi

the beach, seaside 
Each chapter of the four textbooks of Te Whanake focuses on one main area of language or theme. Sometimes related sub-themes are included in some chapters. The following outlines the principal areas of language or situations of each chapter.

\section{Te Whanake 1 Te Käkano}

1. Meeting people, exchanging pleasantries and making kinship connections.

2. Finding out about people's activities.

3. Early morning exchanges, finding out about previous activities and preparations for the day.

4. Making and finding out about arrangements.

5. Breakfast preparations.

6. Breakfast exchanges.

7. Looking for something.

8. Shopping.

9. Telephone conversations.

10. At a hui.

\section{Te Whanake 2 Te Pihinga}

1. Native and endemic birds, fowling, muttonbirding, body language.

2. Describing things, strategies to keep the conversation going and aphorisms.

3. Describing people.

4. Giving directions.

5. Letter writing, describing sounds and talking about the weather.

6. Describing and expressing feelings, tangihanga and the tribes of Tainui.

7. At the beach, fishing and telling a story.

8. Travelling to other places and countries, describing places and the landscape, describing illnesses.

9. Describing animals, colours, the wharenui, ceremonies for opening houses.

\section{Te Whanake 3 Te Māhuri}

1. Whales and dolphins, whaling, international protest movements, conservation and mammalian biology (including body structure, nutrition, the senses and reproduction).

2 . Food and recipes. 
3. Games and sport - traditional and modern (including card games).

4. Geology, volcanic activity and earthquakes, the Tarawera-Rotomahana eruption of 1886.

5. Farming and agriculture, the Māori almanac, the traditional story of Whatihua and Tūrongo.

6. Health and fitness, kawakawa uses for health, the names of countries of Africa.

7. Problems, mishaps, accidents and disasters.

8. Elections and voting.

9. Traditional Māori musical instruments.

10. Māori language, the names of countries of South America.

\section{Te Whanake 4 Te Kōhure}

1. The King Movement and the struggle for settlement of land confiscation grievances by Waikato.

2. Types of sayings in Māori, including whakataukī, whakatauākī, pepeha, kupu whakaari, tongi, kupu whakarite and kîwaha; dialects.

3. Types, function and performance of modern and traditional song and dance.

4. Some Māori leaders - Hoani Waititi, Ngoi Pēwhairangi, Hoani Rangihau, Te Whiti-oRongomai and Tohu Kākahi. The first three were selected partly as a tribute by the writer for the influence they had on him as well as the major contribution they have made to Māoridom and Aotearoa/New Zealand society. The other two were selected because of their efforts in the struggle in the Taranaki.

5. Wars in pre-European times - Ngāti Whātua recorded oral history and the story of Wairangi.

6. Telling jokes and humorous stories.

7. Early accounts by Mâori of the first arrival of the Pākehā.

8. Wars in the Nineteenth Century, especially those of Te Rauparaha, Ngāi Tahu and the war in Waikato.

9. Māori knowledge of the stars, planets and other celestial bodies.

10. The Second World War. 
11. Writing invitations, notices, advertisements and eulogies.

12. The Māori migration to Aotearoa/New Zealand, especially with reference to the Kupe tradition.

13. Māori beliefs, with special reference to wairua, āria, oho, rāhui, māwe, hau, mauri and the Ringatū Church.

14. The use of whakapapa and its relation to mana.

15. Speech-making.

Much of the work for the chapters of Te Māhuri and Te Kōhure has involved an intensive search for high quality oral and written Māori language texts on the themes listed above, preferably of texts not readily available. The Māori language newspapers published in the $19^{\text {th }}$ century and in the first half of the $20^{\text {th }}$ century proved to be a valuable source. Other texts have been written especially for the textbooks. Wharehuia Milroy has provided a range of important texts for Te Kōhure while Tìmoti Kāretu has provided an important text on the Māori performing arts. ${ }^{8}$

\section{Dictionary and Index}

The Te Whanake bilingual dictionary, Te Aka MāoriEnglish, English-Māori Dictionary and Index, is designed for learners of Māori at all levels. It is written on new principles with modern and everyday language essential for learners. As well as the words one would expect in a traditional dictionary, it has encyclopaedic entries designed to provide key information about plants, animals, stars, planets, heavenly bodies, important Māori people, key ancestors of traditional narratives, tribal groups, ancestral canoes, song types, Māori names for institutions, country names, place names and other proper names. There are also detailed explanations of key concepts central to Māori culture. Comprehensive explanations for grammatical items are included, with examples of usage, as are idioms and colloquialisms with their meanings and examples. These have all been included because they are important in communicating in a Māori context, and contribute to understanding and speaking the language in a natural way.

While this dictionary is designed to stand alone, it not only includes all the words used in the Te Whanake series of 
narrative texts and resources, but is indexed to the Te Whanake series, thus giving quick access to topics, maps, illustrations, idioms, colloquialisms, proverbs, tribal sayings, grammar and usage explanations with examples.

\section{Pukapuka Tātaki - Study Guides}

The study guides have been written for the first three stages of the Te Whanake course. They have been written for independent study and, where possible, have model answers at the back of the book. Each chapter is closely aligned to the chapters of the textbook. Some exercises have two parts to them: the first part for individual work and a second part for group activities. As well as giving advice about learning Māori and hints about language learning, the study guides have additional grammatical and usage information with examples.

The focus of each activity in the study guides is on one or more of the following:

- developing reading comprehension skills, especially strategies to help learners understand texts and acquire new language

- helping learn new vocabulary and revise words from earlier in the course

- explaining, understanding and using new grammar structures

- explaining and using idioms

- guided creative writing

In addition, important cultural, environmental, historical, geographical and general knowledge are the topics of some activities, e.g. activities about migration traditions, creation narratives, famous Māori, travel in other countries, native and endemic plants, birds, insects, etc.

Teachers are urged to incorporate the activities of the study guides into their language programmes by assigning particular exercises at the appropriate stages in the programme. 


\section{Sets of audiocassette, videocassette tapes and CDs}

The recorded exercises are designed to help the students practise the new language of a particular chapter and previous chapters. They are an essential part of the language programme, being closely integrated with the textbook, where the instructions for the listening comprehension exercises and visual prompts for speaking practice exercises are contained. There is a gradual shift over the first two student textbooks from a preponderance of meaningful practice drills of new grammatical structures and question-answer exchanges to mainly spoken authentic texts for Te Māhuri and Te Kōhure aimed at developing the listening comprehension skills of the learners.

Learners can use the audiotapes at home or in the language laboratory, where they are able to record their responses in practice exercises. In the language laboratory learners are able compare their language with the model responses provided by native speakers of Māori.

\section{Online resources}

The most recent developments for the Te Whanake series are the incorporation of resources online. These include:

- Converting the audiocassette and videocassette tapes/CDs into digital learning objects that are delivered from our online platform, AUT Online

- Developing new online resources for independent study by learners

- An enhanced version of the dictionary and index.

\section{Converting the audio- and videocassette tapes/CDs to the online platform \\ Currently Te Ara Poutama, the Faculty of Māori} Development at the Auckland University of Technology, is converting the taped audio and video exercises and activities into a digital format for distribution out of an online e-learning platform. This digital content will be made available for playback on Microsoft Windows and Apple computers, television screens, as well as portable media devices such as mp3 players, video iPods and 3G phones.

Adapting the taped audio and video exercises and activities for online use on the internet will have numerous benefits for 
not only the learners, but also the staff and institutions involved in delivering the teaching, e.g.

- Learners will be able to access all the exercises and activities online at minimal or no cost, thus avoiding the expense of purchasing audio- and videotapes or CDs and DVDs;

- Provided learners have a microphone connected to their computer, they will be able to record their responses and submit them to their teachers for quick feedback. With an internet connection, they will be able to submit their exercises for assessment from anywhere in the world;

- Provided teachers have an internet connection, they will be able to mark and give quick feedback to the learners from anywhere in the world;

- This development means that language laboratories will no longer be required for teaching and learning Māori, thus freeing institutions from a major expense for equipment and space will for other purposes.

This is a major development in the methods of learning and teaching Māori.

\section{Developing new online resources}

The goal of the Te Whanake Online project is to develop a series of online interactive modules to complement other Te Whanake resources. Te Whanake Online supports an immersion or game-style approach to language learning. Currently the fifteen modules for the first book in the series, Te Whanake 1 Te Kākano, have been completed and have been available free to use online, or download, since December 2006.9 Institutions can also download the modules and adapt them specifically for their own students. Each module begins with an animated movie introducing the new language of the module. Between nine and sixteen activities in each module provide practice in a wide range of spoken and written language skills, including listening with comprehension, speaking, reading with comprehension, writing and activities to help learn grammatical structures and vocabulary. The project means that Māori language learners will have access to an online resource which is at the forefront of current thinking and practice in language learning online and firmly grounded in a successful and well-established Māori language series of 
texts, study guides, audio-visual resources, a dictionary-index, and teachers' manuals. ${ }^{10}$

\section{Enhanced dictionary and index online}

Since December 2006 the dictionary also has an enhanced online version, including photographs, which is free (http://www.maoridictionary.co.nz). The online version enables new entries, meanings and photographs to be added by the author at any time. ${ }^{11}$ Adding sound for pronunciation and bird calls is also planned in the near future. Also in the pipeline is a texting facility for the dictionary.

Learners using Te Whanake Online will also have access to the online dictionary at the click of a button.

\section{Teachers' manuals}

Each of these contain the following sections:

- Advice and suggestions on teaching methodology and how to use the resources. This section is written in English in the manual for the first textbook, Te Kākano, but in Māori for Te Māhuri.

- A variety of teaching materials for each chapter of the student textbook for photocopying. These are mainly activities designed to develop the learners' speaking skills. Many are activities that contain an information or opinion gap. The purpose of many information-gap activities would be defeated if they were included in a student textbook because the information would be available to all participants. Lists of suitable texts for use by the teacher or learners for further reading or listening activities for each chapter are included in these sections in the manuals for Te Whanake 2 and 3. These have been selected with both the themes of the particular chapter and the level of language in mind.

- The tape scripts of the recorded exercises. These are included to enable the teacher to answer student queries quickly.

- Sample progressive oral, listening, reading and writing tests.

- Lists of useful textbooks on teaching Māori and second languages.

\section{Television series}

As a result of a partnership between TVNZ Education Television (eTV) a colloquial Māori language course, called Te 
Kai a Te Rangatira, was designed to complement the Te Pihinga textbook and resources. This first took the two courses based on these materials into homes and institutions throughout the country in the second semester of 1995 . These courses are aimed at people throughout Aotearoa/New Zealand who are unable to attend regular classes because of the remote location or because of family ties or work commitments and who, under normal circumstances, would not have access to learning the language or the chance to improve their Māori language skills.

Te Kai a Te Rangatira was the first Māori language television series created as part of a tertiary level language course and screened on eTV. The project was an initiative for Māori Language Year by both The University of Waikato and TVNZ. The production funding support of $\$ 1$ million came from Te Māngai Pāho and the Ministry of Education. Support in the planning of the venture also came from a variety of people and organisations including Te Taura Whiri i te Reo Māori, Longman Paul (now Pearson Education New Zealand), Kōtuku Productions, Te Reo Television, Te Māngai Pāho, and the Ministry of Education.

Each programme in the 13-part television series includes a 12 minute drama based in a city restaurant run by the whānau that own the restaurant land as the result of a land claim. Each episode also includes archive or documentary illustration of the course's main themes. Students enrolled in the courses were permitted to videotape the televised programmes.

Five Māori speakers wrote the drama scripts, with former Māori Language Commissioner, Tìmoti Kāretu, and the author of the series as language advisers. The emphasis is on modern colloquial Māori. The story centres on themes that come from the textbook.

However, experience of using the Te Kai a Te Rangatira videos with classes has shown that they are more suited to the Te Whanake 3 Te Māhuri level learners. It is recommended that these video programmes, along with the exercises designed for them, be used at the Te Māhuri level.

As a result of the success of this venture, a similar television series for beginners called Te Kākano was completed for broadcast in mid-1997. Each 30-minute programme contains a 12-minute drama series, explanations of grammar and usage points, and discussions about cultural aspects. All of these are related closely to content in each chapter of Te 
Whanake 1 Te Käkano. Learners will benefit most from the 12minute drama series if their use is delayed until well into the Te Whanake 1 Te Kākano course. In addition, exercises should accompany each episode to ensure that learners develop listening skills and are guided into extracting as much benefit as possible from viewing and hearing the language of each episode.

Efforts are being made for both Te Kākano and Te Kai a Te Rangatira to be available online.

Currently Kura Productions, led by Quinton Hita and Te O Kahurangi Waaka, is working with the author and Te Ara Poutama of the Auckland University of Technology to produce a beginners' Māori language television programme of a hundred 26-minute episodes for the Māori Television Service. It will screen five days a week in peak viewing time, beginning in the second half of 2008. This programme will be closely tied to Te Whanake 1 Te Käkano and the related resources. There will be a dedicated website to supply support resources, including interactive activities, and a forum for learners to discuss language learning experiences as well as to practise new learning. Website material will be developed around the content in each episode. When the viewing stops, the learning continues online. Each televised episode will have three sections: grammar, vocabulary and activities.

\section{Current list of textbooks and resources}

\section{Dictionary and Index}

Te Aka Māori-English, English-Māori Dictionary and IndexHardcopy

Te Aka - Free online: http://www.maoridictionary.co.nz

\section{Beginner level}

- Te Whanake 1 Te Kākano - Second edition of the textbook for beginners.

- Audiotapes/CDs (6) - now updated and adapted to an online medium.

- Te Whanake 1 Te Kākano Pukapuka tātaki - Student study guide.

- Te Whanake Online - free online: http://tewhanake.otago.ac.nz/kakano

- Te Whanake 1 Te Kākano Pukapuka ärahi $i$ te kaiwhakaako - Teachers' manual. 


\section{- Lower intermediate level}

- Te Whanake 2 Te Pihinga - Second edition of the textbook for lower intermediate learners that presumes that the language and skills of Te Käkano have been mastered.

- Audiotapes/CDs (4) - now updated and adapted to an online medium.

- Te Whanake 2 Te Pihinga Pukapuka tātaki - Student study guide.

- Te Whanake 2 Te Pihinga Pukapuka ārahi $i$ te kaiwhakaako - Teachers' manual.

\section{Upper intermediate level}

- Te Whanake 3 Te Māhuri - Second edition of the textbook for upper intermediate learners that presumes that the language and skills of Te Kākano and Te Pihinga have been mastered.

- Audiotapes/CDs (2) - now updated and adapted to an online medium.

- Videotapes (2) - now adapted to an online medium.

- Te Whanake 3 Te Māhuri Pukapuka tātaki - Student study guide.

- Te Whanake 3 Te Māhuri Pukapuka ārahi $i$ te kaiwhakaako - Teachers' manual.

\section{Advanced level}

- Te Whanake 4 Te Kōhure - Second edition of the textbook for advanced learners that presumes that the language and skills of Te Kākano, Te Pihinga and Te Māhuri have been mastered.

- Videotapes (6) - now adapted to an online medium.

\section{Teaching methodology}

While the teaching methodology advocated in using the Te Whanake textbooks and resources is based on the author's accumulated knowledge and experience, it also owes much to that developed by the late Professor Carl Dodson, formerly of the University College of Aberystwyth, University of Wales. His teaching methodology is known as the Bilingual Method and it has much in common with other second-language teaching 
methods currently in use. It is a methodology that was developed in the late 1950s.

\section{The Bilingual Method}

A number of key elements, or principles, in Dodson's Bilingual Method can be isolated, including the following:

1. The methodology for teaching second languages should be based on the way children brought up bilingually acquire their second language - not on the way such children acquire their stronger and preferred language nor on the way monolingual children acquire their only language (Dodson 1978: 4).

2. To enable second-language learners a real opportunity to reach communicative competence, learning procedures should be structured in such a way that the learners can pass from a stage where they are merely practising new language elements (medium-orientated communication) to the stage where they are placed in a situation of having to use these second-language skills for real communication (message-orientated communication). In the latter, language is being used as a tool to satisfy needs other than linguistic ones. ${ }^{12}$ The teacher's aim should be to spend as much time as possible using the target language for message-orientated communication, but there will be a fluctuating process from bilingual medium-orientated communication practice to monolingual message-orientated communication in the target language. As the learners' proficiency and competence increase, less and less time will be spent practising new language in a medium-orientated sense.

3. The units of work in the second language focus on basic situations, with the aim that the learners achieve complete oral and written proficiency for each situation. ${ }^{13}$ At the beginner level the starting point for each situation is the learning of a basic dialogue which will contain some of the vocabulary, structures and idioms necessary for communication in the particular situation.

4. As much time as possible should be spent in message-orientated communication in the target 
language.(Dodson 1981a: 2). Role-play on the one hand and materials and resources on the other offer important avenues for the teacher to involve the learners in mainly message-orientated communication in the classroom. ${ }^{14}$ Bilingual education offers the most effective means of producing bilingual individuals because it is using the target language for message-orientated communication.

5. Dodson has criticised the advocates of direct methods of teaching second languages who ban any use of English from their classrooms. In the Bilingual Method, the mother tongue is used for the acquisition of meaning for new language items and for teaching the learners how to manipulate grammatical structures. ${ }^{15}$

6. Visual aids and the printed word have definite places in the Bilingual Method, but there are significant differences in their uses from some other second-language teaching methodologies. Visual aids are used to help retain the meaning of new language, rather than to provide meaning. Dodson has shown that pictures are not particularly good at helping learners acquire the meaning of new language items. ${ }^{16}$ Neither the teacher nor the learners can be sure that the visuals have conveyed the correct meaning.

7. How should new grammatical structures be taught so that the learners are able to manipulate what they know to cope with different contexts and situations? A clearly defined approach is incorporated in the Bilingual Method to cope with this question.

8. Adjustments have to be made in the basic methodology to cope with the varying ages of the second-language learners, as well as practical aspects in the classroom.

The issue of the use of English in Māori language classes is one that is often debated. Dodson believed that the methodology for teaching second languages should be based on the way children brought up bilingually acquire their second language, not their preferred language. ${ }^{17}$ This is in contrast with all other methods of teaching second languages. 
The aim of direct methods is to replicate how children learn their first and only language without recourse to another tongue, 18 while other methods do not claim to be based on any 'natural' method of learning a language.

Dodson found that although there are many similarities between first and second language acquisition, the two are not the same. The bilingual child does use some tactics to acquire the second language that a monolingual child does not use.

... a young bilingual child when acquiring or strengthening second-language items undergoes a learning procedure different from that followed when acquiring or strengthening his preferred language. 19

Whenever he starts to acquire a new range of secondlanguage items relating to a particular event he does so by using his preferred language as a point of reference. As his aim is to satisfy as quickly as possible his immediate needs in relation to this event, e.g. to satisfy his curiosity or to increase his pleasure, the child will take a number of short cuts in his second-language acquisition to reach this aim:

1. If not already offered, he will ask for the preferredlanguage meaning of words and phrases he cannot understand or about which he is uncertain.

2. He will repeat to himself or, if acceptable to other children, within a group, words and phrases which he has heard in the second language.

3. He will compare and contrast utterances with equivalent meanings taken from his preferred and second language.

4. He will manipulate language by permutating sentence elements in his second language, at times speaking both language versions one after the other or speaking the second-language version after having heard an equivalent preferred-language version. ${ }^{20}$

Elsewhere Dodson includes a further practice step, that of extending and chaining utterances.

They [monolinguals] not only repeat previously heard utterances but also create new utterances by systematically substituting elements from known-utterances and by extending utterances through stitching together combinations of known elements, as well as new combinations of elements 
just discovered in substitution play. As if to savour the newlycreated language items, the child will often chain utterances in quick succession, forming them by all the various strategies at his disposal.

The developing bilingual uses precisely the same strategies of repetition, substitution, extension and chaining - with one major difference: he makes use of two languages. ${ }^{21}$

As well as these five learning tactics, Dodson stresses two other important factors, namely, that these practice steps always occur in a situation framework and that the main aim of the learners is to satisfy their immediate needs.

All the above preliminary processes always occur in what to the child is a situation framework, whether in the child's imagination, or in the real world, and not in isolation even though the child's mind may be focused in varying degrees on the second language rather than fully on the situation itself. On many occasions he will "practise" these processes when by himself after the event.

He will constantly aim to reach a level where he can communicate satisfactorily in order to satisfy his immediate needs (intellectual, physical, emotional, etc.) within an area of experience. In other words, he learns how to cope with his environment mainly by satisfying needs other than those of language, where the second language develops into a tool or vehicle of communication and is not an end in itself. He would not, however, reach this level without the above preliminary steps. It seems that the actual situation, activity or event in which the child finds himself does not afford him a sufficient number of listening and speaking contacts to reach this level, where he is no longer aware of making use of his second language. This type of preliminary language "practising" is constantly being observed in homes where children are being raised bilingually. ${ }^{22}$

Of the five practice steps, or learning tactics, that Dodson has presented, monolingual children use only three. Imitating, substituting and extending and chaining are common to both developing monolingual and bilingual children. In addition to these three, bilingual children also:

1. use the preferred language for meaning acquisition in the second language; and

2. compare and contrast utterances between their two languages. 
Bilingual Method - Learning Sequences

Mainly medium-orientated

Communication

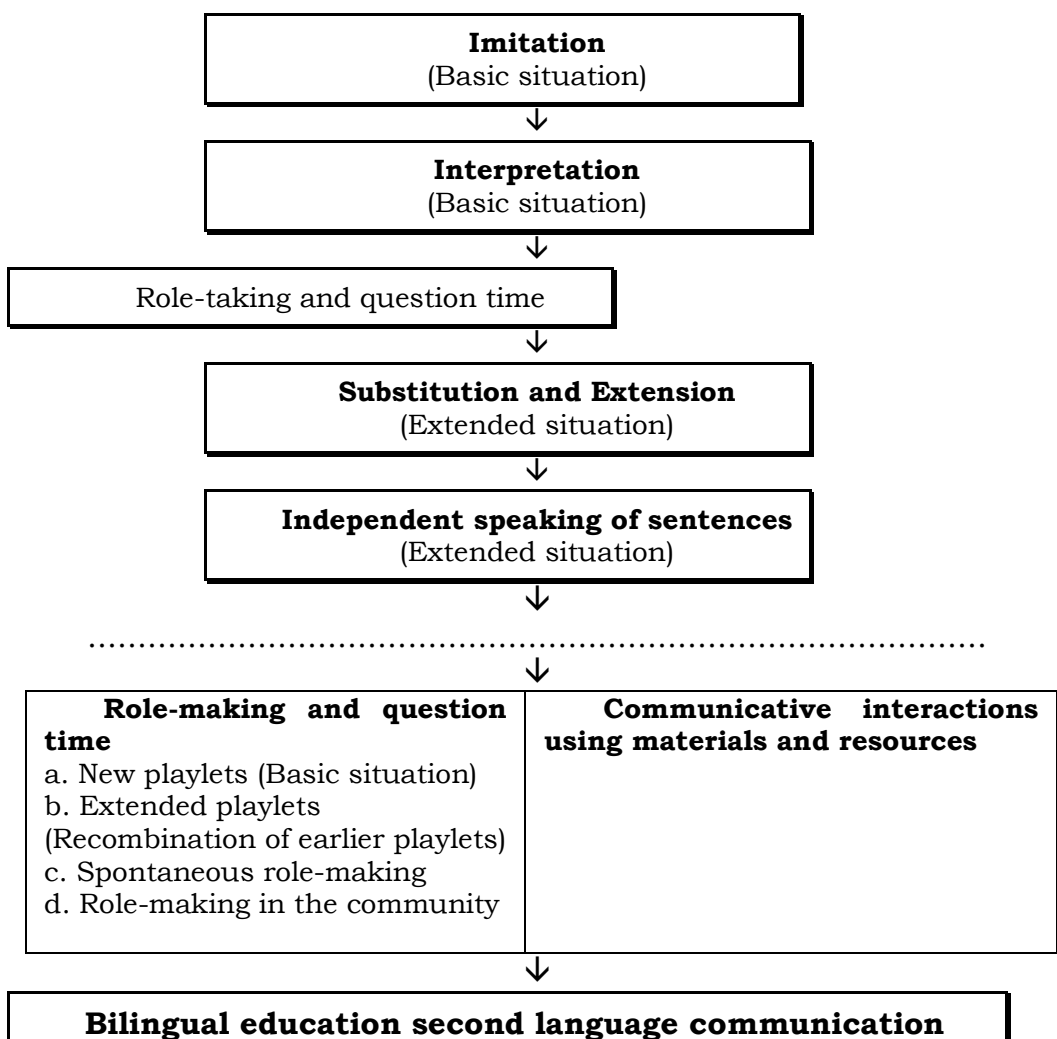

Bilingual education second language communication

Mainly message-orientated

communication $^{23}$

Figure 1 
The Bilingual Method of teaching second languages is an adaptation to the classroom situation of these tactics second language learners use in natural settings. Children learning second languages frequently indulge in verbal play of various kinds. Apart from the pleasure that children get from these activities, they also give the learner the opportunity of practising and experimenting with the target language. As already mentioned, Dodson called this type of language, where the focus is on the language itself, medium-orientated communication, in contrast to language which is used as a vehicle for communication about something other than language, which he has called message-orientated communication. 24

Both types of language are important in both first and second language acquisition. It has been shown that verbal play is easier for the learner because it may not be restricted to context, or in some types, is not reliant on a conversational partner, although it does form the function in other cases of keeping the lines of communication open. ${ }^{25}$

The Bilingual Method aims to take the learner through a series of steps from purely medium-orientated communication through to message-orientated communication for a given language situation. The preliminary practice steps observed by Dodson have been adapted for the classroom situation. The aim is to replicate in the classroom, as nearly as possible, the learning tactics of second-language learners in a natural setting, while streamlining the process to make the most effective use of the time available to the teacher and learners. Figure 1 is an attempt to summarise the steps in the learning sequence of the Bilingual Method in diagrammatic form.

Dodson stressed that medium-orientated and messageorientated communication

\footnotetext{
... should be seen as extreme poles on a continuum where, in the development towards message-orientated communication in any lesson cycle, there are mixtures of both forms in varying degrees and intensities, though the constant aim is for the pupil to be given an opportunity to lose himself in the content (the message) of the materials and to become less and less aware of the linguistic utterances he makes to satisfy his immediate non-linguistic needs generated by the materials, resources and classroom procedures. ${ }^{26}$
} 
Whenever the opportunity arises to engage in messageorientated communication, the teacher should exploit the chance. The constant aim is to spend as much of the lesson time as possible in message-orientated communication. As the course progresses, an increasing proportion of the class time will be spent using the target language to communicate about something other than language.

\section{Other aspects of the teaching methodology}

This section has discussed the main tenets of the Bilingual Method. However, it would be wrong to give the impression that the Te Whanake series adheres slavishly to this method. Many aspects of currently popular second language teaching methods are reflected in the series. For example, the approach used could easily be described as a balanced activities approach as advocated by Jeremy Harmer. ${ }^{27}$

One of the most important aspects in teaching second languages is to create a non-threatening atmosphere in the classroom. In order for learners to make the maximum progress they should not be inhibited about speaking Māori. Overemphasising correctness of language, especially when real communication is taking place, can be quite harmful.

Further details on other aspects of the teaching methodology are included in the three Te Whanake teachers' manuals. In particular the following are discussed:

- Drilling new language;

- The place of English in the Māori language class;

- Using the tape-recorded exercises;

- Teaching and learning vocabulary;

- Role-play;

- Story-telling;

- Games;

- Developing listening and reading comprehension skills;

- Teaching and practising new grammatical structures and usage;

- Teaching and testing writing skills;

- Testing spoken language;

- Using videotapes to develop language skills; and

- Assessment of language skills.

This section has attempted to outline the principles underlying the teaching methodology, but the details of all 
aspects of how to implement the teaching methodology used by the author at the various stages of the course encapsulated in the series would take a much longer description than this treatise allows.

The next part of this commentary will discuss how this methodology is implemented in the textbooks and resources. It will also clarify the reasons for the approach used in designing and writing the textbooks and resources.

\section{Implementing the teaching methodology in Te Whanake textbooks and resources}

This section will initially discuss some of the principles that were applied in creating the textbooks and resources and how the methodology discussed in the previous section is reflected in them. An analysis of one chapter as an example of how the chapters are organised follows. This section concludes with a discussion on the selection of vocabulary.

\section{Some principles that were applied in creating the textbooks and resources}

The textbooks have been written with several principles in mind, including the following:

- One of the reasons that the textbooks and tape recordings were produced was to provide students with resources they could use at home in order to accelerate their progress. Adult learners usually have limited time with their teacher. The textbooks and recorded exercises were produced to enable students to take more control over their learning and to free the teacher to spend more time in activities using the language, particularly speaking tasks.

- Because different vocabulary varies in its usefulness, it is important to make sure that the learners have good control of the high frequency words before moving on to the less frequently used vocabulary. In the Te Whanake series the most useful language is introduced first.

- Consequently the chapters in the first textbook in the series are centred on everyday situations. The stage at which particular language items are introduced is governed by their usefulness rather than the difficulty of the form. For example, 
the $a$ and $o$ categories, which even some advanced second language learners of Māori have difficulty with, is introduced early, albeit in stages, because it is so integral to the language.

- Grouping antonyms, synonyms and items in a lexical set together has been avoided because it causes confusion for the learners. ${ }^{28}$ Words with a similar form but different meanings are not introduced together as this has been shown to cause confusion for the learner. For example, learners are likely to confuse the meanings of hoihoi (be noisy) with hōiho (horse) if they are introduced together.

- While there is no recognition of 'standard' Māori, in the early stages of the course vocabulary items peculiar to a particular dialect are avoided. For example, pakupaku is introduced well before moroiti for 'small'; the former being widely used while the latter in modern Māori is restricted mainly to western dialects and particularly to speakers from the Tainui region. This does not mean that teachers should not encourage learners to use their own dialects. Where teachers have reasonably homogeneous groups of learners with the same tribal origins they should, whenever possible, teach that dialect. However, fluent speakers of Māori should be familiar with all the main dialects of Māori. Te Kōhure and its accompanying videos have been designed partly to cater for this need for advanced learners to be familiar with all the main dialects of Māori in Aotearoa/New Zealand.

- While there are no generally accepted figures for the rate at which learners should meet new vocabulary in a language course, there was an awareness by the author that when presenting a written or listening text the number of new words per familiar ones should be restricted, although this would vary according to the type of activity. For example, during extensive reading new words should not be met at a rate greater than one or two per hundred known words if learners are to gain pleasure from reading (Nation 1994: v).

- New vocabulary in the series is introduced in a number of ways. The majority of new words occur in context in the dialogues or texts in each chapter, but some are introduced in the examples given in the He whakamärama sections in each chapter. In some chapters vocabulary lists are provided, but it is expected that the teacher will spend time explaining and using these words in activities. Others will occur in extensive reading and extensive listening. For example, in Te Māhuri extensive listening activities are focused on the audio- and 
videotaped material, while extensive reading exercises are designed around the autobiography of Hēmi Pōtatau, He Hokinga Mahara.

- Once language items (vocabulary, grammar and usage) have been introduced they are recycled as frequently as possible, although it is expected that the teacher will play an important role in this process. Writers on second language teaching have highlighted the importance of recycling previously presented lexis. 29

- Not all aspects of a particular language feature are necessarily introduced at the same time, whether it is a grammatical structure, a usage feature or the various meanings of a new word. Where it is deemed that to explain all aspects at a specific time would overburden the learner, the various aspects are introduced at different stages of the course. Time is allowed to enable learners to master one aspect before introducing the next.

- There is now much more awareness among skilled second language teachers that for new grammar and vocabulary items to become part of learners' productive language they need to be guided through stages from an emphasis on the form of the language through to the stage where the new language is being used for real communication. This is sometimes described as guiding the learners from a focus on form, or pre-communication activities, through to a focus on meaning, or communicative activities (e.g. see Littlewood 1981: 85-95). In Dodson's terminology, discussed in some detail in the previous section, this is guiding learners from medium-orientated to message-orientated language. Consequently, a variety of speaking, listening, reading and writing exercises and activities are included in each chapter with this aim in mind.

- English is used only in the grammar and usage sections and in giving the meaning of each word in the vocabulary lists. In Te Māhuri and Te Kōhure grammar and usage are explained in Māori. However, Māori examples of each syntactical item are always given with an English translation.

- While some attention is given to cultural aspects in Te Kākano, teachers will have many opportunities to increase their students' awareness of Māori values, beliefs, history and cultural practices. Increasing attention is paid to these aspects as the Te Whanake course progresses. An important task of 
the Māori language teacher is to create a Māori atmosphere in the class and institution, not just through the physical surroundings in the classroom, but more importantly through the way activities are conducted and the attitudes encouraged in the learners. Concepts such as manaakitanga (hospitality, caring, sharing), aroha (concern for others), mahi tahi (working together), wairua (spirituality), mana (authority, prestige, right, influence, control) and whanaungatanga (relationships) should be incorporated into the classroom procedures. Many of the exercises and activities of the Te Whanake series allow the teacher to incorporate such attitudes into the classroom procedures.

- In a number of countries bilingual and immersion schools have been shown to be one of the most effective ways of producing bilingual individuals. (For a fuller discussion and references to studies on bilingual education programmes see Moorfield 'Implications for schools of research findings in bilingual education'. In W. Hirsh (ed.) Living Languages. Bilingualism \& Community Languages in New Zealand. Auckland,1987: 31-43.) In these schools the second language is used as the teaching medium, as well as for classroom management, conversation and discussion. The topics for each chapter of the more advanced textbooks of Te Whanake and their video- and audiotapes have been chosen with this aim in mind. The intention is that not only are the students learning new language but they are also expanding their knowledge about the topics being discussed in the texts, whether it be knowledge of Māori astronomy, history, spirituality, music, migration traditions, oratory, humour, charismatic leaders, whales and dolphins, food, sport and recreation, agriculture, health, elections, protest movements, volcanology or seismology. By using Māori as the teaching medium, for much of the learning time the focus is on the subject matter, rather than on the language itself.

- Both modern and traditional Māori music is, of course, part of Māori culture. Waiata in their various forms are an important way of increasing language proficiency, as well as being useful in adding variety to the lesson. Exercises using songs are included at various stages of the course. Hirini Melbourne's songs have been included in each chapter of the tape recordings because they give practice in the language used in the particular chapter. They are modern and original compositions that are likely to appeal to the students. The 
lyrics for these songs are included in the tape script in the teachers' manuals.

For people to be able to communicate effectively in a language, they need to know more than just its sounds, grammar and vocabulary. They must also learn what sorts of language are appropriate to the situation they are in and the people they are with. They must learn to use a range of expressions that are commonly used for particular functions in the language. How to express oneself, to inform, to influence, to demand, to promise, to ask for something, to make sense of what people say, to interpret irony and metaphorical speech, to switch codes depending on who they are talking to, to take turns in conversation, to control a topic and to give way to another participant in the conversation, all need to be learnt. Most of these are culturally based, so while there will be skills transferred from English, there are aspects which will need to be acquired in Māori which are different.

In the past, teachers have concentrated on the teaching of sentences as self-contained units, paying little attention to the way sentences are used in combination to form stretches of connected discourse. For the learners to become proficient in Māori, they need to be exposed to, and to learn the sorts of conversational speech that use the routines, idioms and set sayings commonly used by native speakers of Māori. The dialogues and texts of each chapter of the Te Whanake textbooks and tape recordings, together with purposeful verbal communication in the classroom, go some way towards developing these skills.

The dialogues, He whakamārama and Hei whakahuahua sections of each chapter are obviously concentrating on what Dodson calls medium-orientated communication. Other sections of each chapter could be placed at various stages along the continuum towards what he would class as message-orientated communication.

Many of the activities in the textbooks and teachers' manuals are examples, or templates, that can be used by teachers to create new activities. These activities are an important way of placing learners in situations where the language is being used as a tool to communicate about things other than the language itself. Second language teaching experts are much more aware now of how important it is that learners spend a significant proportion of class time in 
activities that involve 'real' communication, hence the emphasis on this in the Te Whanake series.

In Te Whanake some attention is paid to teaching language learners strategies to improve their language learning skills, including the following:

- A description of the characteristics of a good language learner (in the introduction to Te Whanake 1 Te Käkano). An understanding of the qualities that the most successful second language learners have and the strategies they use to become fluent in the target language is helpful to adult beginners. Likewise an awareness of why children appear to learn second languages more easily than adults can help to overcome possible difficulties that adult learners may experience.

- Listening and reading comprehension exercises lead the learners through a series of steps to elicit meaning and to focus on specific language items. These steps give learners a strategy for attacking difficult oral or written texts. The teachers' manual for Te Māhuri (pages 2 to 5) also explains in some detail these strategies. Teachers are also directed to further reading on this approach. 30

- Ways to learn new vocabulary (Te Māhuri page 24). Again, further reading is available in the Te Māhuri teachers' manual (pages 5 to 6).

- Verbal strategies to keep the conversation going when the learner's vocabulary is limited (Te Pihinga pages 5 to 6).

- Ways to check that the listener is understanding (Te Pihinga page 6).

\section{An analysis of the content of one chapter from the Te Whanake series}

Each chapter of the four textbooks concentrates on a topic likely to be of interest to adult learners. This is particularly true of Te Māhuri and Te Kōhure. This is what could be classed by Dodson as bilingual education. This following analysis of the first chapter of Te Māhuri is an example of the types of exercises and material contained in the chapters of the textbooks.

In Chapter One of Te Māhuri the students study whales and dolphins. Included in the chapter is a text written by the author about: 
- the different types of whales and dolphins and their Māori names;

- the terms for the different parts of a whale or dolphin;

- the origins of these animals;

- how they breathe;

- their food;

- a description of an eye witness account of orca whales hunting dolphins;

- whale sounds;

- whale strandings;

- how whales and dolphins reproduce;

- the hunting and protection of whales and dolphins;

- Greenpeace; and

- Māori knowledge and understanding of these animals.

As well as this text written by the author in Chapter One of Te Māhuri, five authentic texts are included.

1. The first is a text written by Roka Paora of Te Whānau-a-Apanui about whaling in her tribal territory on the East Coast (pages 9 to 17). This text was written in 1979 for a secondary school publication, but for some reason had never been published. The author added a map and illustrations. A reading comprehension exercise (Te mahi tuhituhi 2) was designed to focus on a general understanding of what the text is about, leading to a more detailed understanding of the text and its structure.

2. The second text is an extract from what was originally a radio broadcast in Māori on whaling on the East Coast (pages 18 to 20). This was later transcribed and published in Te Ao Hou Number 19 in 1957. The author of Te Whanake added illustrations.

3. The third text is a short article that appeared in the Māori newspaper Te Waka Maori o Niu Tirani on 8 October, 1874. This text is about the whaling season on the East Coast from Māhia Peninsula to the East Cape. This article is used as a practice exercise using the procedure to extract and learn new vocabulary discussed prior to the newspaper article.

4. A story from Māori oral tradition about a pet whale, Tutunui (pages 26 and 27). After reading this story students are placed by the teacher in groups of five or 
six people. The task of each group is to prepare a drama about part, or all, of the story to present to their class (Hei mahi whakaataata).

5. The final authentic text and activity for the students to complete in Chapter One of Te Māhuri is to read an advertisement from a Māori magazine, Te Ao Hou Number 45, 1963, which describes briefly the nature of the godwit and urges people to preserve this bird. Students are asked to use this advertisement as a model and to write a similar advertisement for people to help protect whales.

Other activities included in this chapter are designed to develop the learners' knowledge of whales and dolphins as well as to give them the language skills to discuss this topic. These activities would, in the main, be placed near the messageorientated communication end of Dodson's continuum. In Chapter One (Te Wāhanga Tuatahi) of Te Māhuri they include the following:

- Several oral communication activities (Hei mahi kōrero).

The first of these requires the students to conduct a survey

of their fellow students (Te mahi kōrero 1). The second is done as a group activity with each person preparing one of seven topics on whales and dolphins and then teaching that topic to the rest of the group (Te mahi kōrero

The third activity requires each person in a group of five to prepare a talk about a particular fish variety (Te mahi kōrero

A further information-gap activity for groups of between seven and 15 students is contained in the teachers' manual (Te Whanake 3 Te Māhuri Pukapuka ārahi $i$ te kaiwhakaako pages 20 to 28).

- An exercise where students have to label a diagram of the parts of a whale after having read the relevant section in the author's text (Hei mahi pānui, tuhituhi hoki).

- Listening comprehension exercises using the audiotape (Hei mahi whakarongo, tuhituhi hoki). The first of these requires the students to listen to a description of a group of whalers and to add those things described that have been omitted from the illustration. The second of these exercises requires the students to answer questions about each paragraph on the audiotape and its illustration in the textbook. 
The third asks the students to listen to a traditional story and then explain a whakatauki (aphorism) at the end of the tale. To do this they would have had to understand the story.

The next listening exercise (page 32) is taken from a short contemporary comment in Māori about conservation of marine resources. Students are required to listen to the recorded broadcast in order to complete the gaps in a written summary of the talk.

- A writing exercise where the students are asked to write a newspaper article on whaling on the East Coast (Hei mahi pānui, tuhituhi hoki). The sources for their information could be from the first three authentic texts included in the chapter.

- A section (He huarahi hei ako i ngā kupu hou) suggesting ways to help learners develop skills to discover the meaning of new vocabulary items from their context without resorting to a dictionary. This leads into the follow-up activity using the 1874 authentic text.

- An oral communication activity where students work in pairs. The teacher provides (from the teachers' manual) each student with a list of words taken from the chapter. They take turns to describe the meaning of the word to their partners who have to guess the word being described.

- The autobiography in Māori by Hēmi Pōtatau He Hokinga Mahara is used mainly for extensive reading activities to accompany Te Māhuri. In this chapter the students are asked to find the answers to nine questions listed in the textbook (Hei mahi pānui). These questions are general ones designed to focus on the main points covered in the first chapter of Hēmi Pōtatau's book.

- As well as the activities discussed above, the teachers' manual for Te Māhuri has further activities which the teacher can use including:

- A list of 13 stories that the teacher could use for a variety of activities.

- A reading comprehension activity using an extract from Te Māhuri on the sounds that whales make. After moving from general to more specific questions designed to help the learners understand the text, the students focus on a particular grammatical construction that is also explained on pages 28 to 29 of Te Māhuri. 
Many of the ideas for reading, writing, listening and speaking activities included in the Te Whanake series have originated directly or indirectly from the sources listed at the end of each teachers' manual in the series.

This description of Chapter One of Te Māhuri has been included to illustrate the types of activities designed to develop the language skills of the students and how the activities reflect the teaching methodology. In terms of Dodson's diagrammatic representation in Figure 1, most would fit into the mainly message-orientated section of his model. On the other hand, the explanations of the six grammatical or usage forms contained in Chapter One of Te Māhuri (pages 27 to 32) belong in the mainly medium-orientated language part of Dodson's model in Figure 1.

These activities would sit comfortably in other current second language teaching methodologies, including that advocated in the internationally recognised RSA/Cambridge Certificate in English Language Teaching to Adults (CELTA).

\section{Vocabulary}

As stated previously, one of the principles followed in creating these resources was to teach the most useful language first. However, with the almost total absence of research of this nature, the author was obliged to rely on his own experience and intuition in learning and teaching the language. While this would appear to be a rather imprecise approach, by choosing the most common everyday situations and topics early in the course it seems that this, together with the author's teaching experience and intuition, resulted in a satisfactory graduation of the frequency of vocabulary items.

In 1982 Richard Benton published a basic word list for Māori. ${ }^{31}$ The data on which the list was based consisted of 120,000 words of written text of which there were 3,541 different words. ${ }^{32}$ Because Benton's data came from only written sources and a relatively restricted range of texts, his results should be treated with some caution. However, it was found that

the 650 most valuable words were reasonably well dispersed, and accounted for more than 90 percent of the 106 , 608 occurrences of words actually counted. About 500 of these 
words were 'content' words; the rest were pronouns, particles,

demonstratives and other 'function' words and substitutes. ${ }^{33}$

An analysis of the 650 most valuable words listed by Benton reveals that only five do not appear in the vocabulary lists of the first three student textbooks of Te Whanake. They are:

$\begin{array}{ll}\text { kāreti } & \text { college } \\ \text { Pākehā } & \text { Pākehā } \\ \text { rēme } & \text { lamb } \\ \text { toi } & \text { to fish for eels } \\ & \text { with a bob } \\ \text { waireka } & \text { soft drink }\end{array}$

However, of these only rēme does not appear in $\mathrm{He}$ Hokinga Mahara, the extensive reading text that supplements Te Mâhuri. Most of these core words are introduced in the first textbook, Te Kākano, while 82 are first introduced in Te Pihinga and the remaining 15 do not appear until the third textbook in the series. This suggests that the author's intuitive approach was more reliable than might have been expected.

Perhaps one could surmise that in the absence of any research into the frequency of grammatical structures, that a similar reliance on the author's intuition for these could be as reliable.

Finally in this section, it is important to point out that despite the variety of activities included in the Te Whanake series, it is expected that teachers will add their own exercises and games and adapt the material contained in the student textbooks and teachers' manuals to suit the needs of the learners. The types of exercises and games included in the series were selected partly to provide examples for teachers so that they could use them as models to create their own activities. In this way they can build up a set of resources suited to the learners they are teaching.

\section{The Pedagogic Grammar of Te Whanake}

The He whakamärama sections of each chapter of the student textbooks contain the explanations for all the new grammatical structures and idioms that occur in the dialogues and texts of the particular chapter. They are written in English in the first two textbooks but in Māori in Te Māhuri and Te 
Kōhure. The explanations of these grammatical items are written as clearly as possible with a minimum of linguistic terminology.

For each grammatical or usage feature a number of examples are included to illustrate each, with the relevant feature being underlined. English translations of these examples are given to help student understanding. The examples have sometimes been taken from authentic texts while the author has created others. These examples are sometimes also used to introduce new vocabulary.

Aspects of some of the more difficult grammatical features are introduced gradually over a number of chapters. This is deemed to be a more effective way of ensuring that the learner masters these. For example, the particle ai has a number of separate but related usages. Each of these is introduced at various stages in the four textbooks. A linguist would probably discuss these various aspects together.

The pedagogic grammar uses the grammatical approach taken in the grammar Let's Learn Maori by Bruce Biggs, but without most of his linguistic terminology. Words are classed according to the way they are used in the language. Biggs was the first writer to abandon the traditional grammatical model completely. He described the phrase structure of Māori according to the tenets of the structural linguists of the Bloomfieldian school. ${ }^{34}$

When writing each particular grammatical feature the author of the Te Whanake series first consulted existing Māori language grammar books, textbooks and articles that included those listed at the end of each of the teachers' manuals of the series. Where the author's own knowledge suggested that together these sources were inadequate in explaining a particular grammar feature, further research was carried out with fluent speakers of Māori. In particular Wharehuia Milroy and Tìmoti Kāretu were invaluable in clarifying aspects of grammar and usage.

Examples of usage features that seem not to have been discussed elsewhere in the literature at the time the Te Whanake books were written included the following:

- The use of kei as a formal respectful way of addressing someone. It is quite usual to hear this usage in formal speech making. This usage is explained on pages 174 and 175 of Te Māhuri. In that same section the use of $T e$ to precede some personal names as a way of showing respect is also explained. 
- An example of a special use of another particle, hei, is discussed on page 36 of Te Pihinga. This specialised use of hei when discussing kinship relationships was also not present in the literature on the grammar of Māori.

- The particular use of mahi to indicate abundance, e.g. Kua kapi katoa taua wăhi ite mahi a te whare. (That place was totally covered with an abundance of houses.) This usage is explained on page 109 of Te Māhuri.

- The particular use of $k o$ and its positioning in the sentence in comments following the T-class possessives, e.g. $I$ haere mātou $i$ runga $i$ te tono a ō māua hoa ko Hèmi. (We went with regard to the request of Hēmi's and my friend.) See pages 124 to 125 of Te Māhuri for the full explanation of this feature.

- The particular use of mai and atu as in the following example:

Kì tonu te wharepuni $i$ te tangata, Pākehā mai, Māori mai. (The meetinghouse was full of people, Pākehā and Māori.) This usage is explained on pages 92 to 93 of Te Māhuri.

- The use of $k a$... ai to mean 'consequently', 'hence', etc, e.g. He aha tātou ka kōrero tahi aí? (Then why don't we talk together.)

This usage is explained on pages 27 and 28 of Te Kōhure.

- The use of the N-class possessives to mean 'as a result of' or 'while' as illustrated in the following example. Nōku $i$ te kura, ka timata au ki te ako $i$ te reo. (While I was at school I began to learn the language.) See pages 81 to 82 of Te Kōhure.

- While the $a$ and $o$ categories have been discussed in most Māori grammars, the subtle distinction in their use discussed on page 164 of Te Māhuri had not appeared in print before.

- The explanation about the use of wareware on pages 30 and 31 of Te Māhuri was not found in other grammars.

However, most grammatical features discussed in the Te Whanake series are to be found somewhere in other Māori grammars or Māori language textbooks, although the presentation is unique to the Te Whanake series. Bauer ${ }^{35}$ and Ray Harlow ${ }^{36}$ certainly cover most grammatical structures of the language.

Most of the grammatical features of Māori are covered in the first three textbooks of the series. The appendix lists the grammar and usage features of Māori introduced in each chapter of the four textbooks. 


\section{Conclusion}

In presenting this commentary an attempt has been made to outline the nature of the Te Whanake series and to make explicit the teaching methodology that these resources have been designed for. The design of the textbooks and resources and the types of activities that have been developed are such that they could be used in a variety of teaching contexts, as well as in self-tutoring situations.

The textbooks and resources have been created to assist teachers and adult learners of Māori. They provide the basis for a structured programme of study progressing from beginner level through to advanced learners of Māori, with a variety of activities to ensure that all language skills are developed. The aim is that at the end of the course encapsulated in Te Whanake, the learners will be fluent and literate in Māori, being able to communicate comfortably in most situations where Māori is used as a medium of communication. Reaching this aim with the Te Whanake series is most likely to be attained where there are the following main ingredients:

1. A skilled teacher who is fluent and literate in Māori. The teacher needs to be knowledgeable about second language teaching methods and how second languages are learnt.

2. Adult or teenage learners of Māori who are highly motivated to learn and use the language with sufficient time to learn it in a reasonably intensive manner.

These resources also aim to produce speakers who will continue to improve their ability in Māori after completing Te Whanake. Some emphasis in the course is placed on training the learners to take control of their own learning and to extend their knowledge beyond what is contained in the Te Whanake series. Likewise, it is not intended that teachers restrict their students' exposure to Māori only to what is contained in the series. It is expected that the teacher will provide extension activities. Certainly, cultural aspects should be part of the context in which the language is taught.

The teaching methodology underpinning the work is important to whatever success the series has in helping learners become fluent in the language. As has been shown in 
this commentary, to become fluent in a language and to communicate effectively requires much more than an understanding of its sounds, grammar and vocabulary. The various exercises that have been devised for each chapter of the Te Whanake series (in the textbooks, audio- and videotapes and the teachers' manuals) are particularly important in helping produce fluent speakers of Māori who are also literate in the language.

The teaching experience of the author has shown that where the two important ingredients listed above are present the aim that learners will be fluent and literate in Māori, being able to communicate comfortably in most situations where Māori is used as a medium of communication, can be achieved.

Many Māori adults have a strong desire to learn Māori. The Te Whanake series of textbooks, study guides, recorded exercises, teachers' manuals and the dictionary provide an avenue for them to achieve their aim. With this series universities and other tertiary institutions now have the resources to enable them to provide an effective way to teach Māori from beginner through to the advanced levels.

\section{Notes}

R. A. Benton, The Flight of the Amokura. Wellington, 1981, pp. 25-6.

Ibid., p. 26.

Kāretu, T.S. 1989. 'From Language Studies to Department of Māori', in The University of Waikato. Twenty-five Years. Hamilton, 1989, p. 72.

Personal communication from Ray Harlow who introduced the first Māori language course at the University of Otago.

B. Biggs, Let's Learn Maori, Wellington, 1973, p. 52.

Op. cit.

R. Harlow, A Māori Reference Grammar, Auckland, 2001, p. 31.

This aspect of the series has been covered elsewhere in more detail - see Moorfield 2006: 107-116.

9 http://tewhanake.otago.ac.nz

10 T.M. Ka'ai, McDonald, J., Moorfield, J.C. Te Whanake Online: An interactive resource for Māori language learning. He Puna Körero - Journal of Maori \& Pacific Development. Vol 7, No 2, September 2006 pp. 62-67

11 The use of the online dictionary is steadily growing with, currently, more than 20,000 visits per month averaging more than seven searches per visit.

12 C. J. Dodson, 'Foreign language teaching and bilingualism.' In Bilingualism and British Education : The Dimensions of Diversity. London: Centre for Information on Language Teaching, (CILT Reports and Papers, no. 14), 1976, p. 80; C. J. Dodson, 'Bilingual Education in Bilingual Areas.' Aberystwyth: University College of Wales, Aberystwyth. Unpublished paper 
delivered at the 5th International Conference: Bilingual Education in Multinational Schools, Milan, Italy, 1st-5th November, 1978, pp. 8-9; C. J. Dodson, 'The Schools Council Project on Bilingual Education in the Secondary Schools of Wales: Methodology.' Aberystwyth: University College of Wales. Unpublished article, 1981, pp. 1-2.

13 Op. cit.

14 C. J. Dodson, 'The Schools Council Project on Bilingual Education in the Secondary Schools of Wales: Methodology.' Aberystwyth: University College of Wales. Unpublished article, 1981, pp. 3, 10, 12, 15.

15 C. J. Dodson, Language and the Bilingual Method. London, 1967, pp, 71; 83-97; 102-112.

16 Ibid., pp. 6-11; 15.

17 C. J. Dodson,. 'Schools Council Bilingual Education Project 1968-75 - An Independent Evaluation.' Aberystwyth: University College of Wales. Unpublished report, 1975, p. 4; ibid., 1976, p. 86; C. J. Dodson, 'Bilingualism, Language Teaching and Learning'. British Journal of Language Teaching. v. 21 no. 1, 1983, p. 6; C. J. Dodson, 'Living with two languages.' Journal of Multilingual and Multicultural Development. v. 4, no. 6, 1983, pp. 412-413.

18 A. A. Hill, 'Language analysis and language teaching', in J. Michel (ed.), Foreign Language Teaching. New York, 1967, p. 10

19 W. Butzkamm, \& C.J. Dodson., 'The teaching of communication : From theory to practice', in International Review of Applied Linguistics. v. 18, no. 4, 1980, pp. 289-309.

20 C. J. Dodson, 1975 , p. 3.

21 C. J Dodson, Bilingual Development and Education. Aberystwyth: Centre for Bilingual and Language Education, The University College of Wales, Aberystwyth, 1983.

22 C. J. Dodson, 1975 , pp. 3-4.

23 Adapted from C. J. Dodson, $1967 \& 1981$.

24 C. J. Dodson, 1978 , pp. 8-9.

25 E. Hatch, 'Discourse analysis and second language acquisition', in E. Hatch (ed.) Second Language Acquisition: A Book of Readings. Rowley, Massachusetts, 1978, p. 411.

26 C. J. Dodson, 'The Schools Council Project on Bilingual Education in the Secondary Schools of Wales: Methodology.' p. 3.

27 J. Harmer, The Practice of English Language Teaching. London, 1991, pp. 41-42.

28 I.S.P. Nation, (ed.), New Ways in Teaching Vocabulary. Alexandria, Virginia, 1994, p. iv.

29 R. Gairns, \& S. Redman, Working With Words. A guide to teaching and learning vocabulary, Cambridge, 1986, pp. 93-95.

30 F. Grellet, Developing Reading Skills. A practical guide to reading comprehension exercises. Cambridge, 1986; Harmer 1991; A. Matthews, M. Spratt, L. Dangerfield (eds.), At the Chalkface, Hong Kong 1991; C. Nuttall, Teaching Reading Skills in a Foreign Language. Oxford, 1982.

31 R. A., Benton, H Tumoana \& A. Robb, The First Basic Maori Word List, Wellington, 1982.

32 Ibid., pp. 7-8

33 Ibid., p. 8.

34 B. Biggs, 'The Maori Language Past and Present', in E. Schwimmer, The Maori People in the Nineteen-Sixties, Auckland, 1968, p. 68.

35 W. Bauer, The Reed Reference Grammar of Mãori. Auckland, 1997.

36 R. Harlow, 2001. 